Viotti, C. and Mansour, A., 1969. Tertiary Planktonic Foraminiferal Zonation from the Nile Delta, Egypt, U.A.R., Part I: Miocene Planktonic Foraminiferal Zona- tion. Proc. 3rd African Micropal. Colloquium. 425, pls. 1-5. Cairo.

\title{
44.5. THE EUSTATIC HYPOTHESIS AND THE PRE-PLIOCENE CUTTING OF THE RHONE VALLEY
}

\author{
Georges Clauson, Laboratoire de G'eographie Physique, Universite d'Aix-Marseille, 13, Aix-en-Provence, France
}

The finding of an extensive layer of evaporites in the deep drillings in the Mediterranean revives a new interest in the hypothesis of a temporary isolation of this sea at the end of the Miocene. Since this idea has already received support from the interpretation of boreholes within the Rhone Valley in southern France, I have been invited to first trace the history of this hypothesis, and then examine how it provides a unique solution to a number of problems of continental paleogeography.

\section{BACKGROUND AND HISTORY OF THE "DENIZOT HYPOTHESIS"}

The eustatic hypothesis is far from being a new idea. Ever since Depéret (1895), it has been entertained by a number of authors. However, they always relied on a worldwise cause for sea-level change without ever really commenting on its origin.

It was Denizot who first offered an explanation for the extraordinary amplitude of the regression which was believed to have occurred in the Mediterranean basin. In a paper published in 1952 on the Pliocene in the Rhone
Valley, he explicitly developed the concept of an isolation of the Mediterranean. Consequently, I refer to it here as the "Denizot hypothesis." The original text is worth quoting: ${ }^{1}$

"Il y eut une régression de la fin du Miocène, d'une très grande généralité, qu'on reconnait aussi sur le versant atlantique: c'est un tel system de vallées que la mer pliocène devait envahir, à l'embouchure actuelle de la Loire. Mais en outre, pour ce qui est de la Méditerranée à ce moment, les détroits espagnols et marocains s'étant fermés, et avant que ne s'ouvre celui de Gibraltar, il s'est produit un séparation complète de cette mer. Elle s'est alors réduite à une lagune, et a évolué indépendamment suivant les conditions climatiques: il y eut baisse de son niveau, en se bordant d'une frange littorale où peuvent singulièrement voisiner étangs saumâtres et lagunes de concentration. Telle est maintenant, en moins grand, la Mer Caspienne.

A la phase suivante s'ouvre le détroit de Gibraltar: la Méditerranée reprend le caractère de mer normale et transgresse sur ses côtes en même temps que fait l'Altantique. Cette mer envahit alors le réseau fluvial qui venait de se creuser et notamment la vallée du Rhône, objet de la

\footnotetext{
${ }^{1}$ Editor's translation-

"There was a regression of the sea at the end of the Miocene over a widespread area which was observed also on the Atlantic coast: it is such a system of valleys that the Pliocene sea had to invade to the mouth of the Loire itself. With the connecting passageways across Spain and Morocco closed and the Gibraltar Strait not yet opened, the Mediterranean at that moment became completely isolated. It was subsequently reduced to a lagoon and evolved independently according to climatic influence: there was a drop in sea level such that the bordering coastal fringe became
}

occupied by brackish ponds and saline lagoons. On a smaller scale, the Caspian Sea is such an example.

In the following period the Strait of Gibraltar opened: the Mediterranean took back its normal character and the sea transgressed its coasts at the same time as did the Atlantic. This sea invaded the fluvial network previously incised, in particular the valley of the Rhône which is the object of present study. Other authors have often commented on the various aspects of the Pliocene transgression: its widespread occurrence evoking a raising of the entire surface of the sea-that is an eustatic movement." 
présente étude. Les auteurs ont abondamment commenté les divers aspects de cette transgression pliocène: sa généralité évoque un mouvement d'ensemble de la surface marine, un mouvement eustatique."

As was mentioned, the occurrence of Pliocene deposits at a lower base-level than Miocene formations has caused consternation for all previous authors. Fontannes (1882) first outlined the contours of this marine transgression which would be subsequently called "the Piacenzian ria." He showed the unconformable generalized erosion along the old channel cutting and interpreted the actual setting as a consequence of the tectonic deformations of the terminal Miocene.

The finding of marine Pliocene deposits, with a thickness in excess of 100 meters, in drilling sites located in the Valence plain, led Depéret (1895) to the following conclusion ${ }^{2}$ : “ . . . le fond de la vallée marine pliocène était creusé très en dessous de la vallée actuelle." And he adds: ${ }^{3}$ "Lá Méditerranée pénètre à l'interieur de la vallée du Rhône suivant un trajet remarquablement identique à celui du Rhône actuel. .." Finally, he gives the following interpretation: ${ }^{4}$ " ... sans doute par suite d'un abaissement des lignes de rivages de la mer, de puissants phénomènes de ravinement on entaillé dans la masse du Miocène des vallées identiques, pour la plupart au moins, à nos vallées actuelles." The regression is situated after the orogenic phase of the terminal Miocene (Phase Rodanienne).

We have to wait until 1952 in order to find a statement concerning a correlation between the Mediterranean eustatism and the (temporary) isolation of this basin. This relationship had most likely been suggested to Denizot by the drilling program of the 1950's in Camargue. The deep drillings there revealed an unexpected and very irregular thickness (locally in excess of $1000 \mathrm{~m}$ ) of marine sediments of Pliocene age; the sediments are lying on a very differentiated topography cut by real subaerial canyons (Beaufort et al., 1954).

Taking into account other contemporary wells which had demonstrated the lack of a Neogene thalweg beneath the Rhône straits at Donzere (Figure 1), Denizot limited the influx of the Miocene cutting to the course downstream of Donzere. The marine sediments of Pliocene age located upstream, underneath the Valence plain, were interpreted as a deposit related to a subsiding axis (ombilic de subsidence). All this rendered frail the conviction of Depéret (1895) and of Baulig (1953).

Recent drillings have once more renewed the question. They have been undertaken in the Malataverne sill (located eastwards of the straits of Donzere) and underneath the river bed between Saint-Vallier and Tournon. The first ones discovered the Pliocene clay masked at the surface by the

\footnotetext{
2 "... the bottom of the Pliocene marine valley was incised very much below the present valley."

3 "The Mediterranean penetrated to the interior of the Rhône valley along a course remarkably similar to its present one..."

4 “. ... without doubt as a result of a lowering of the shore line of the sea, powerful gulleying had cut into the Miocene substratum valleys for the most part identical to the present ones."
}

alluvial blankets of Quaternary age, thus demonstrating the passage of the Neogene Rhône through this sill. We can understand why the Donzere wells did not identify the pre-Pliocene thalweg in a location where it never had existed! The second group of wells, beneath the recent alluvium, penetrated the same clays for a thickness of about 80 meters. When terrninated at +45 meters above sea-level, the drillings had not yet reached the metamorphic basement rocks. On the basis of the gradient of the slopes, Mandier (1969) located the pre-Pliocene thalweg some 50 to 100 meters further, or 130 to 180 meters beneath the Rhône valley. This information is very interesting, because up to that time all authors had been thinking that the present day river bed had reached the base of the Neogene cutting.

Numerous data from the boreholes has permitted one to reconstruct with a certain degree of accuracy the physiography of the pre-Pliocene valley (see Figure 2). It turns out to be a continuous and very narrow valley, excavated to a level which is everywhere lower than the present Rhône thalweg. The known outcrops of marine sediments of Pliocene age allow one to follow this canyon all the way for a distance of almost $300 \mathrm{~km}$ from the Mediterranean shore, near Grau du Roi, to Lyon. The point of view expressed by Depéret in 1895 is thus entirely confirmed.

\section{ROLE OF EUSTATIC SEA-LEVEL CHANGE IN THE PRE-PLIOCENE CUTTING OF THE RHÔNE VALLEY}

For a long time, the insufficient number of drilling sites having a deep penetration, and their contradictory results, rendered a synthesis difficult. The more recent interpretations and/or conclusions are not much better than the earlier ones, since they depart with an a priori assumption: some are fixists, others are mobilists.

In order to try to clearly evaluate all facts, it is necessary to not consider a general analysis, but to distinguish between the five major events which characterize the geologic history since Tortonian time. They are as follows:

1) The late Miocene tectonic phases ("Phase Rhodanienne"),

2) The Messinian eustatism,

3) The intra-Pliocene tectonic activity,

4) The post-Pliocene tectonic activity, and

5) The Quaternary glacio-eustatism.

As an example, if we sum the effects of episodes 3 ) and 4), one can convince himself of the possibility of excluding the reality of of episode 2). Since it is necessary to avoid this kind of confusion, we have to select a field of investigation in which such confusion is impossible. The intra-Pliocene tectonic activity is one that involves differential movements affecting the Rhone Valley: the Camargue, the Pujaut trench, and the Valence plain. Contrary to the intra-Pliocene tectonics, the post-Pliocene tectonics are essentially epeirogenetic. All the Rhône Valley downstream has been deformed by subsidence, while the upstream part underwent a general uplift.

In between Lyon and Valence, there is an area which has not been affected by intra-Pliocene deformation. Here, in the straits upstream from Tain-Tournon, we can evaluate the exclusive effects of the post-Pliocene tectonic activity. 


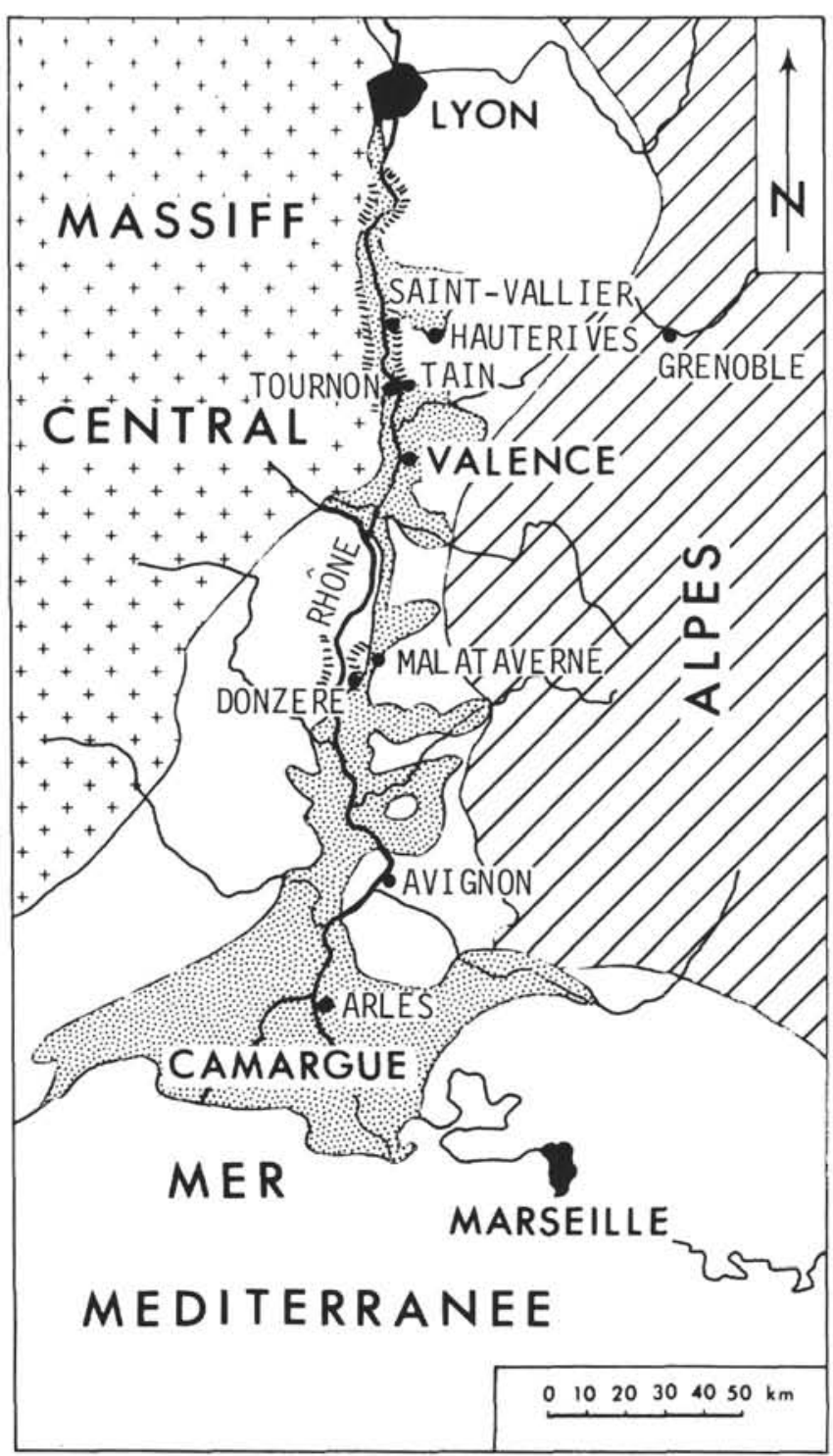

Figure 1. The present course of the Rhone River and the outline of the former "Piacenzian ria" (after R. Balésio, 1971).

This gorge, about $20 \mathrm{~km}$ long, is incised into homogeneous material of the Hercynian basement (granite and gneiss). From one end to the other, the deep wells have demonstrated that the present Rhône river lies some 200 meters above the pre-Pliocene thalweg. Since the area did not undergo differential tectonics either during or after Pliocene times, the morphologic surfaces created at the end of Miocene times have never been internally deformed. An intra-Pliocene subsidence can be excluded because it would have had to follow only the winding contours of the valley, a very unlikely possibility.

The Hercynian basement is levelled by an erosional surface. The post-Pliocene epeiorogenic uplift can be estimated at 200 to 300 meters since on both sides of the Rhône Valley this erosional surface lies some 350 meters above sea level. It represents a chronological datum and a paleogeographic indicator. From a chronological standpoint, it can be dated by means of the latest Tortonian layers which transgress over it. From a paleogeographical standpoint, it has been defined by Pelletier (1953) as a pediment dominated by an inselberg. At the time of such formation, this surface, now hanging, was sensibly at base level (i.e., at sea level). It represents for us the starting point for all the subsequent evolution.

When the Pliocene sea penetrated into the Rhône Valley, the sea level was near that of the present day. This is based on the conclusions of various authors that the Pliocene deposits were deposited under shallow water conditions. The difference of the Pliocene level with reference to the level of the sea in late Miocene times is at least 350 meters at a distance of some $200 \mathrm{~km}$ from the present-day shoreline. It results in a spectacular difference in the amount of erosion evidenced. Two hypotheses can be put forward in order to explain it. They are: either a general uplift related to the RhOdanian phase (see Fontannes, 1882, Faucher, 1927, Bourdier, 1962; Ballesio, 1971, Mandier, 1969) or a negative eustatic movement (see Depéret, 1865, Baulig, 1953). At this point we cannot make a choice between these two hypotheses; however, in the perspective of the Rhðdanian Phase, we remark bewilderment that such a vertical displacement would have been already achieved between this initial detection of the orogenesis (retreat of the sea, elaboration of the sediments on the slopes, etc.) and the commencement of actual channel cutting.

The formations representing the Pliocene infilling are marine near the base and brackish to fresh water in the upper part. What height did they reach? In the Rhône Valley at St. Desirat, marine clays referred to the Piacenzian are found at 220 meters above sea level (Mandier, 1969). It is an erosional limit in a gorge which has been deeply recut during Quaternary time. Outside the valley, Pliocene marine deposits are found up to 280 meters above sea level (Chateau de la Sizeranne); also, the lacustrine marls of Hauterives are as high as 300 meters. Near the end of the filling episode, the sea level was sensibly the same as in late Miocene times. In the meanwhile it should have dropped at least 350 meters.

According to the tectonic hypothesis, this implies a double movement of opposite trend, the result of which should be zero. These movements should have responded to strongly different rhythms: rapid uplift, followed by an extremely slow subsidence. We have to add to the preceding scheme a new Plio-Quaternary uplift on the order of 300 meters in order to account for the observed Quaternary cutting. In this perspective, from the end of the Miocene the area under discussion should have oscillated with movements of constant amplitude but of various rhythms. Since no precise argument has been proposed so far to justify these conditons, this hypothesis seems to us unrealistic.

On the other hand, the obstacles which led Denizot to limit the effects of the regression exclusively to the continental environment have been removed by the recent drillings in the area. So far, only the eustatic hypothesis can explain all the available data concerning the pre-Pliocene subaerial erosion. According to this model, we can more 
I, 1. TORTONIEN: phase of the peri-alpine sea

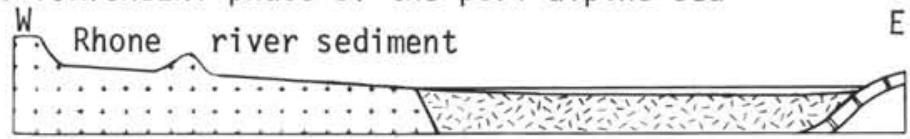

I,2. UPPER MIOCENE: lacustrine phase

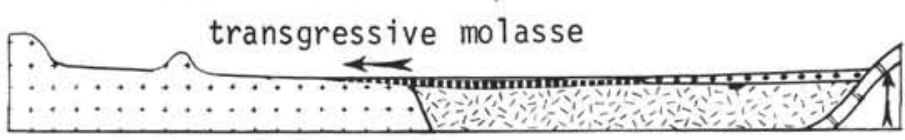

I,3. UPPER MIOCENE: Formation of a thin veneer of piedmont accumulations.
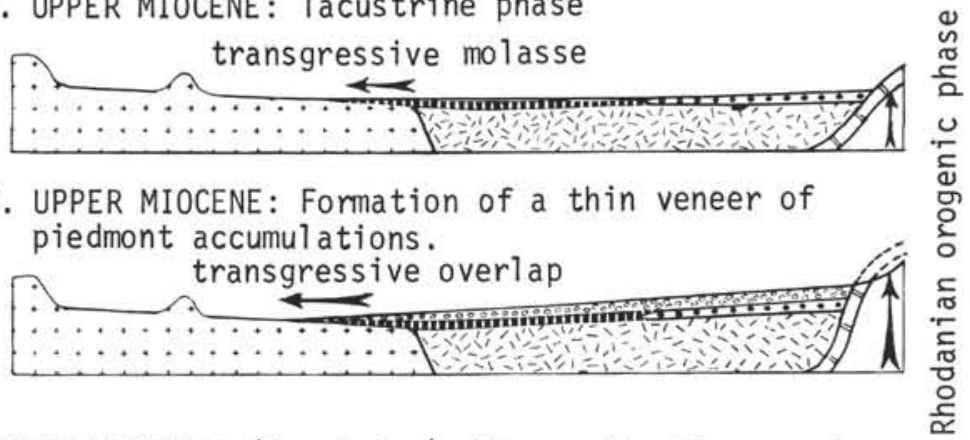

II. UPPER MIOCENE (Messinian): Phase of valley erosion,

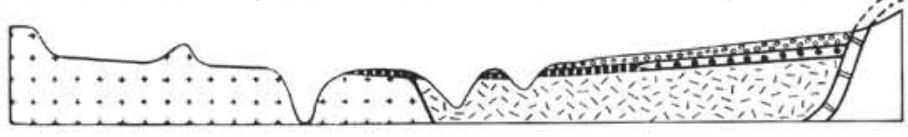

Messian eustatic movement

III,1. MIDDLE PLIOCENE (Plaisancian): Marine

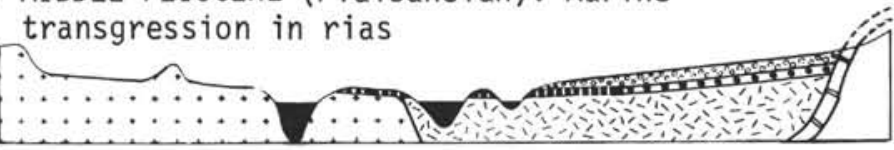

III,2. MIDDLE PLIOCENE (Hauterives Zone): lacustrine phase

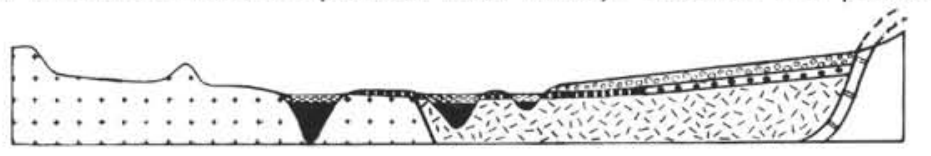

III,3. VILLAFRANCHIAN : formation of second piedmont

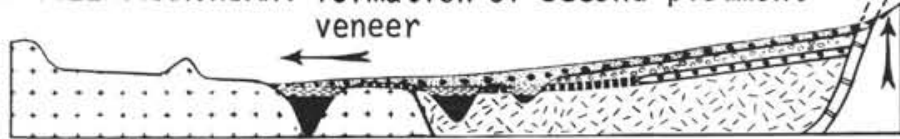

离

IV. QUATERNARY: phase of renewed valley erosion
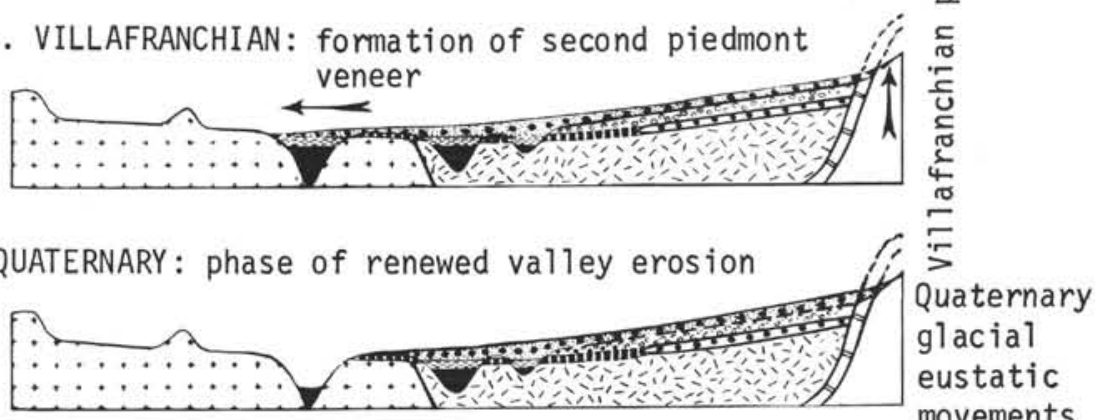

movements

Quaternary alluvium

Hauterives

.

Villafranchian conglomerates

\section{lacustrine marls}

Plaisancian blue marl

Upper Miocene conglomerates

[man Lacustrine and conglomerates of the same age

區楒罚 Vindobonian marine molasse

Mesozoic of the subalpine chains

$\because \ldots$ Hercynian basement

Figure 2. The evolution of the paleogeography of the central valley of the Rhone since the Miocene.

satisfactorily account for why the channel cutting always appears as a linear gorge and why it is deeper downstream than upstream. Taking into account the extended desicca- tion of the entire region we also better understand why the erosion took place only along the most important axis of the hydrographic network, without affecting the minor 
tributaries. The generalized desiccation accompanied by dryness is also documented by the data concerning the late Miocene floras (Grangeon, 1960; Ginsburg, 1968; MeonVilain, 1970) and faunas (Gaudry, 1873, Guerin and Mean, 1971) (landscape and population of steppe and/or savanna type) as well as by the data concerning the continental sedimentology (Chamley and Colomb, 1967) (rubefaction; predominance of montmorillonite).

Because of the local climatic conditions, only the rivers originating from the high drainage of the Alps would be expected to keep their connection with the very depressed erosional level.

Finally, the eustatic hypothesis alone can explain how the Pliocene transgression took place. Actually, in Camargue where the Pliocene succession is extremely thick, the transgression occurs in Tabianian times (clays with Sphaeroidinellopsis) while upstream, where the Pliocene filling is far less thick, the marine transgression occurred later in the Pliocene (blue marls referred to the Piacenzian).

Notwithstanding the impressive consequences of the Messinian drop in sea level, we cannot discount the Rhodanian orogenic phase. A chronologic displacement exists, indicating that the two phenomena are discrete. The regression comes after the orogenesis, being its consequence. This orogenesis in the sub-alpine domain (and at the epidermic level) has essentially a tangential component. In this respect, it differs from the following movementsPliocene and Pleistocene in age-which are of epeirogenetic type. This Rhodanian phase, associated with a world-wide eustatism (related to the orogenesis under discussion or to the beginning of the Antarctic glaciation?) indirectly caused the isolation of the Mediterranean basin. Under the influence of a dry climate, which was probably further deteriorated by the sinking of the water-table, this sea underwent a regression without precedent, during which the evaporites discovered in the abyssal plains were deposited.

\section{ACKNOWLEDGMENTS}

This paper was invited for inclusion into this chapter by M. B. Cita, following discussions at the Congress on the Mediterranean Neogene Stratigraphy at Lyon, in September 1971. She has kindly provided for translation of the original French text into English.

\section{REFERENCES}

Ballesio, R., 1971. Le Pliocène rhodanien. Docum. Lab. Géol. Univ. Lyon, H.S. 201.

Ballesio, R. and Truc, G., 1967. Contribution à l'étude du Néogène de la moyenne vallée du Rhône. Le Miocène supérieur et le Pliocène du Haut-Comtat Venaissin. Trav. Lab. Geol. Fac. Sci. Lyon. No. 14, 79.

Baulig, H., 1928. Le Plateau Central de la France et sa bordure méditerranéenne, A. Colin (éd.), 590 p. 1953. Les hauts niveaux de base du Pliocène. Rev. Geogr. Lyon. 28 (3), 205.

Beaufort, L., Bruneau, J., Crepin, A. and Jullian, Y., 1954. Ampleur de 1 l'érosion pontienne et du comblement pliocène en Camargue. Bull. Soc. géol. Fr. (Paris). sér. 4. 13,175 .

Bonnet, A. and Duboul-Razavet, C., 1952. Contribution à la connaissance du Bas-Rhône. Bull. Soc. géol. Fr. (Paris). ser. 6. 2, 123.
Bonnet, A., 1962. Liaison des tectoniques profondes et superficielles en Camargue. Bull Serv. Carte géol. France (Paris). 59 (269), 251.

Bourcart, J., 1962. La Méditerranée et la révolution du Pliocène. Livrë à la mémoire du prof. P. Fallot. Mém. $h$. sér. Soc. géol. Fr. 1, 103.

Bourdier, F., 1962. Le Bassin du Rhône au Quaternaire. Géologie et Préhistoire. Paris, éd. du C.N.R.S. 2, 364 p.

Carbonnel, G., 1969. Les ostracodes du Miocène rhodanien (Thèse) Docum. Lab. Géol. Fac. Sci. Lyon. 32 (fasc. 1-2), $469 \mathrm{p}$.

Chamley, H. and Colomb, E., 1967. Premières données sur la sédimentation argileuse du Miocène supérieur dans le bassin de Cucuron (Vaucluse). Présence de niveaux lacustres à attapulgite. C. R. Somm. Soc. géol. Fr. 230.

Combaluzier, C., 1932. Le Miocène de la Basse-Provence. Bull. Serv. Carte géol. France. 35 (182), 183 p.

Cornet, C., 1965. Evolution tectonique et morphologique de la Provence depuis l'Oligocène. Mém. Soc. géol. Fr. No. $103,1$.

Demarcq, G., 1961. Distinction entre les nappes miocène et pliocène de conglomérats à galets calcaires impressionnés dans la vallée du Rhône. Bull. Serv. Carte géol. France. (Paris) 58 (264), 179.

1964, Les faciès du Miocéne supérieur et du Pliocène inférieur et la limite Miocène-Pliocène dans la vallée du Rhône. C. R. $2^{\grave{e}}$ Colloque du Néogène méditerranéen. (Sabadell-Madrid) (fasc. 9), 77.

1970. Etudé stratigraphique du Miocène rhodanien. Mém. B.R.G.M. (Paris) No. 61, 257 p.

1971. Base de nos connaissances sur le Miocène de la valleé du Rhône. Docum. Lab. Géol. Univ. Lyon, H.S. 3 .

Denizot, G., 1939. Etude géologique de la Crau, la Camargue et l'étang de Berre. Trav. Lab. Géol. Univ. Marseille. 2, 4 .

1952. Le Pliocène dans la vallée du Rhône. Rev. Géogr. Lyon. XXVII (4), 327, fig. 9, pl. 1.

Deperet, C., 1895. Apercu sur la structure générale et l'histoire de la formation de la vallée du Rhône. Ann. Géogr. (Paris) 432.

Duboul-Razavet, C., 1956. Contribution à l'étude géologique et sédimentologique du delta du Rhône. Mem. Soc. géol. Fr. No. 76, 1.

Faucher, D., 1927. Plaines et Bassins du Rhône Moyen. Thèse Lettres Grenoble. Imprimerie Charpin et Veyne, Valence.

Fontannes, F., 1882. Note sur l'extension de la faune de la mer pliocène dans le S. E. de la France. Bull. Soc. géol. France (parris) sér. 3. 2, 103.

Gaudry, A., 1873. Animaux fossiles du Mont Léberon (Vaucluse). Etude sur les vertébrés. F. Savy (Ed.), Paris, $112 \mathrm{p}$.

Ginsburg, L., 1968. L'évolution du climat au cours du Miocène en France. Bull. Ass. Nat. Orléan., (Orléans, H.S.), XLI, 11 p.

Glangeaud, L., 1967. Epirogenèses ponto-plio-quaternaires de la marge continentale franco-italienne du Rhône à Genes. Bull. Soc. géol. de France. IX (7), 426.

Grangeon, P., 1960. Contribution à l'étude des terrains tertiaires, de la tectonique et du volcanisme du Massif du Coiron Trav. Lab. Geol. Fac. Sci. Grenoble. 36, 143.

Guerin, C. and Mein, P., 1971. Les principaux gisements de mammifères miocènes et pliocènes du domaine rhodanien. Docum. Lab. Géol. Univ. Lyon, H. S. 131.

Latreille, G., 1969. La sédimentation détritique au Tertiaire dans le Bas-Dauphiné et les régions limitrophes. Docum. 


\section{G. CLAUSON}

Mandier, P., 1969. La vallée épigénique du Rhône d'Andance à Tournon. Rev. Géogr. Lyon. XLIV (2), 117.

Mein, P. and Truc, G., 1966. Faciès et association faunique dans le Miocène supérieur continental du Haut-Comtat Venaissin. Trav. Lab. Géol. Fac. Sci. Lyon, H. S. No. 13, 273.
Meon-Vilain, H., 1970. Palynologie des formations miocènes supérieures et pliocènes du Bassin du Rhône. Doc. Lab. Geol. Fac. Sci. Lyon. No. 38, 167 p.

Pelletier, J., 1953. La bordure orientale du Massif Central de Vienne à Tournon. Rev. Géogr. Lyon. XXVIII (4), 357. 